\title{
TELAAH EPISTEMOLOGIS PENDEKATAN SAINTIFIK MATA PELAJARAN PENDIDIKAN AGAMA ISLAM
}

\author{
Kusaeri \\ Universitas Islam Negeri Sunan Ampel Surabaya, Indonesia \\ E-mail: kusaeri@uinsby.ac.id \\ Rangga Sa'adillah \\ Sekolah Tinggi Agama Islam Taswirul Afkar Surabaya, Indonesia \\ E-mail: ranggaopni@gmail.com
}

\begin{abstract}
This article seeks to find out the intersection between scientific approach and Islamic religious education as a subject matter. The scientific approach adopts scientific steps in building scientific knowledge, i.e. such featuring dimensions as observation, reasoning, inquiry, validation anD and description of scientific truth. Since the scientific approach is regarded as too empirical, rational and logical. In Cartesian sense, it contradicts the logical structure of the subject of Islamic religious education. Five aspects of Islamic religious education (the Qur'ân, Hadîth, Aqîdah Akhlaq, Fiqh, history of Islamic culture, and Arabic language) have different characteristics, even demand a non-scientific logics such as intuition and revelation. Aqîdah (belief), for example, which consists of the doctrine of monotheism (tawhid) is difficult to be scrutinized through empirical evidence. There are some other examples in this field which are difficult to be analyzed by means of scientific approach. Through library research, this article nevertheless finds that the logic of scientific approach and Islamic religious education can be integrated, since revelation and reason are mutually supportive.
\end{abstract}

Keywords: Scientific approach; Islamic religious education; 2013 curriculum.

\section{Pendahuluan}

Tahun 2013 pemerintah memberikan perubahan paradigma dalam pembelajaran. ${ }^{1}$ Perubahan paradigma yang dimaksud di antaranya

1 Pembelajaran adalah proses interaksi antara peserta didik dengan pendidik dan sumber belajar pada suatu lingkungan belajar. Lihat Salinan Peraturan Pemerintah 
adalah pola pembelajaran yang semula berpusat pada guru (teacher centered) menjadi pembelajaran berpusat pada peserta didik (student centered). Pola pembelajaran yang satu arah (interaksi guru-peserta didik) menjadi pembelajaran interaktif-bukan hanya terbatas antara guru dan peserta didik. Pola pembelajaran semacam ini memungkinkan terjadinya interaksi antara guru, peserta didik, bahkan dengan masyarakat dan dengan lingkungan alam. Interaksi yang tidak terbatas antara guru dan peserta didik menjadikan peserta didik mengambil sumber belajar dari berbagai sumber. Dengan demikian peserta didik dapat menimba ilmu dari siapa saja dan dari mana saja.

Perubahan paradigma selanjutnya terdapat pada perubahan pola pembelajaran, yang dulunya pasif menjadi pembelajaran aktif. Pola belajar sendiri menjadi belajar berkelompok. Pembelajaran alat tunggal yang hanya mengandalkan verbalisme menjadi pembelajaran keterampilan aplikatif dan berbasis alat multimedia. Hal yang menarik dari perubahan paradigma pada tahun 2013 ini adalah pola pembelajaran pasif menjadi pembelajaran kritis. $^{2}$

Perubahan paradigma ini diikuti dengan perubahan langkahlangkah pembelajaran yang terdiri dari mengamati, menanyakan, mengeksplorasi, mengasosiasi, dan mengomunikasikan. Perubahan paradigma dan langkah pembelajaran ini untuk selanjutnya disebut sebagai pendekatan saintifik. ${ }^{3}$

Pendekatan saintifik mengadopsi langkah-langkah saintis dalam membangun pengetahuan, yakni penonjolan pada dimensi pengamatan, penalaran, penemuan, pengabsahan, dan penjelasan tentang suatu kebenaran. Dengan demikian, proses pembelajaran harus dilaksanakan dengan dipandu nilai-nilai, prinsip-prinsip, atau kriteria ilmiah. Salah satu kriteria ilmiah tersebut adalah materi pembelajaran harus berbasis pada fakta atau fenomena yang dapat

\footnotetext{
Republik Indonesia Nomor 32 Tahun 2013 tentang Perubahan atas Peraturan Pemerintah Nomor 19 Tahun 2005 tentang Standar Nasional Pendidikan, Pasal 1 nomor 19.

2 Sebenarnya perubahan paradigma pembelajaran bukan hanya yang tertulis diatas. Untuk lebih mengetahui selengkapnya lihat Salinan Lampiran Peraturan Menteri Pendidikan dan Kebudayaan Nomor 69 Tahun 2013 tentang Kerangka Dasar dan Struktur Kurikulum Sekolah Menengah Atas/ Madrasah Aliyah.

3 Kusaeri, "Evaluasi Penerapan Kebijakan Pendekatan Saintifik pada Kurikulum 2013 dari Perspektif Pendidikan Islam" (Surabaya: Lembaga Penelitian Universitas Islam Negeri Sunan Ampel, 2014), 2.
} 
dijelaskan dengan logika atau penalaran tertentu; bukan sebatas perkiraan/spekulasi, khayalan, legenda atau dongeng semata. ${ }^{4}$

Selain kriteria ilmiah yang menjadi alur pikir, pendekatan saintifik harus dihindarkan dari alur pikir non-ilmiah (intuisi). Dalam perspektif pendekatan saintifik, intuisi dimaknai sebagai kecakapan praktis yang irasional dan individual atau subjektif. Intuisi merupakan kemampuan tingkat tinggi yang dimiliki oleh seseorang atas dasar pengalaman dan kecakapannya. Istilah ini sering juga dipahami sebagai penilaian terhadap sikap, pengetahuan, dan keterampilan secara cepat dan berjalan dengan sendirinya. Kemampuan intuitif itu biasanya didapat secara cepat tanpa melalui proses panjang dan tanpa disadari. Namun demikian, intuisi sama sekali menafikan dimensi alur pikir yang sistemik dan sistematik. ${ }^{5}$

Pendapat yang demikian ini bertentangan dengan alur pikir mata pelajaran (mapel) PAI. Sebagai subject matter, PAI terdiri dari lima aspek, yaitu al-Qur'ân Hadîth, Akidah Akhlak, Fiqh, Sejarah Kebudayaan Islam, dan Bahasa Arab. ${ }^{6}$ Lima aspek PAI tersebut memiliki karakteristik yang bermacam-macam, bahkan menghendaki pola pikir yang disebut oleh pendekatan saintifik sebagai pola pikir non-ilmiah. Penulis mengambil aspek Aqidah sebagai contoh. Dalam hal ini, apabila lima langkah tersebut di atas diterapkan dalam aspek Aqidah, maka akan terlihat adanya kerancuan. Hal ini karena pendekatan saintifik mengharuskan guru menyuguhi siswa materi pembelajaran yang berbasis pada fakta (bisa diindra secara empiris). Sementara itu, aspek Aqidah yang di dalamnya berisi muatan ketawhîd-an sulit untuk disajikan fakta yang dapat dibuktikan secara empiris. Contohnya adalah ketika membahas tentang keyakinan adanya Malaikat Izrail sebagai malaikat yang bertugas mencabut nyawa. Pertanyaan yang kemudian muncul adalah "Bagaimana guru memberikan fakta mengenai Malaikat Izrail yang bisa diindra atau disajikan secara empiris?" Kesimpulannya adalah apabila aspek Aqidah terlalu "dipaksa" untuk mendekati fakta empiris, maka dapat menjadikan supremasi akal lebih tinggi dari pada otoritas wahyu.

\footnotetext{
${ }^{4}$ Dalam modul workshop Model Pembelajaran Saintifik Mata Pelajaran Pendidikan Agama Islam, 6.

${ }^{5}$ Ibid.

6 LihatPeraturan Menteri Agama Nomor 2 Tahun 2008 tentang Standar Kompetensi Lulusan dan Standar Isi.
} 
Hal yang sama berlaku juga pada kriteria non-ilmiah dalam pendekatan saintifik yang menolak intuisi sebagai sarana memperoleh kebenaran. Padahal, menurut al-Shaybanî, intuisi menjadi dorongan bagi seseorang agar dapat merasakan getaran hati akan Rabb-nya dan merupakan bagian terpenting dalam menerima pengetahuan. ${ }^{7}$ Namun dengan problematika tersebut, akankah pendekatan saintifik dinafikan begitu saja? Oleh karena itu, perlu adanya pembahasan dan analisis yang tajam untuk mencari titik temu antara pendekatan saintifik dengan mapel PAI.

\section{Makna Pendekatan Saintifik}

Menurut Kellen, pendekatan merupakan titik tolak atau sudut pandang proses pembelajaran. Pendekatan merujuk pada pandangan tentang terjadinya suatu proses yang sifatnya masih sangat umum. Dua pendekatan dalam pembelajaran teacher centered approaches dan student centered approaches menurunkan masing-masing strategi pembelajaran. ${ }^{8}$ Teacher centered approaches menurunkan direct instruction, pembelajaran deduktif atau pembelajaran ekspositori sedangkan student centered approaches menurunkan strategi pembelajaran inkuiri dan diskoveri serta pembelajaran induktif.

Student centered approaches digunakan dalam kurikulum 2013 agar lebih memberikan kesempatan terbuka pada siswa untuk melakukan kreativitas dan pengembangan potensi melalui aktivitas secara langsung sesuai dengan minat dan keinginan. ${ }^{10}$ Melalui student centered approaches terlahir pendekatan saintifik. ${ }^{11}$ Pendekatan saintifik merupakan pendekatan pembelajaran yang mengadopsi langkahlangkah saintis dalam membangun pengetahuan melalui metode ilmiah. Model pembelajaran yang diperlukan adalah yang memungkinkan terbudayakannya kecakapan berpikir saintifik serta berkembangnya sense of inquiry dan kemampuan berpikir kreatif.

\footnotetext{
7 Lihat Omar Mohammad al-Toumy al-Syaibany, Falsafah Pendidikan Islam, terj. Hasan Langgulung (Jakarta: Bulan Bintang, 1975), 268.

${ }^{8}$ Rusman, Model-model Pembelajaran Mengembangkan Profesionalisme Guru (Jakarta: PT RajaGrafindo Persada, 2012), 380.

${ }^{9}$ Bandingkan dengan penjelasan dalam Lampiran IV Peraturan Menteri Pendidikan dan Kebudayaan Republik Indonesia Nomor 81A Tahun 2013 tentang Implementasi Kurikulum, 4-5. Dalam PERMEN tersebut juga dijelaskan mengenai pembelajaran langsung dan pembelajaran tidak langsung.

${ }^{10}$ Rusman, Model-model, 382.

${ }^{11}$ Martadi, Wawancara, Sidoarjo 22 Januari 2015.
} 
Pendekatan saintifik tidak memandang hasil belajar sebagai muara akhir. Akan tetapi ia memandang bahwa proses belajar sebagai hal yang sangat penting. Oleh karena itulah pendekatan saintifik menekankan keterampilan proses. Pendekatan ini memberikan penekanan pada proses pencarian pengetahuan daripada transfer pengetahuan di mana siswa dipandang sebagai subjek belajar yang perlu dilibatkan secara aktif dalam proses pembelajaran sementara guru berperan sebagai fasilitator yang membimbing dan mengoordinasikan kegiatan belajar. Siswa diajak untuk melakukan proses pencarian pengetahuan berkenaan dengan materi pelajaran melalui berbagai aktivitas proses saintifik sebagaimana dilakukan oleh para ilmuwan (scientist) dalam melakukan penyelidikan ilmiah. Dengan demikian, siswa diarahkan untuk menemukan berbagai fakta, membangun konsep, dan nilai-nilai baru yang diperlukan untuk kehidupannya secara mandiri. Fokus proses pembelajaran diarahkan pada pengembangan keterampilan siswa dalam memproseskan pengetahuan, menemukan dan mengembangkan sendiri fakta, konsep, dan nilai-nilai yang diperlukan.

Pendekatan ini mencakup pada penemuan makna (meanings), organisasi, dan struktur dari ide atau gagasan, sehingga secara bertahap siswa belajar bagaimana mengorganisasikan, melakukan penelitian, bahkan penemuan sendiri (inquiry). ${ }^{12}$ Pendekatan ini memberikan kesempatan peserta didik mengembangkan keterampilan berpikir tingkat tinggi. Dengan demikian, siswa lebih diberdayakan sebagai subjek belajar yang harus berperan aktif dalam memburu informasi dari berbagai sumber belajar sedangkan guru lebih berperan sebagai organisator dan fasilitator pembelajaran.

Pendekatan saintifik bercirikan penonjolan dimensi pengamatan, penalaran, penemuan, pengabsahan, dan penjelasan tentang suatu kebenaran. Dengan demikian, proses pembelajaran harus dilaksanakan dengan dipandu nilai-nilai, prinsip-prinsip atau kriteria ilmiah serta mendorong dan menginspirasi peserta didik mampu memahami, menerapkan, dan mengembangkan pola berpikir yang rasional dan objektif dalam merespons substansi atau materi pembelajaran. Di samping itu, proses pembelajaran harus terhindar dari sifat-sifat atau

12 Pendekatan saintifik juga dapat mendorong siswa untuk melakukan pembelajaran inkuiri. Dalam inkuiri pengetahuan dan keterampilan yang diperoleh peserta didik bukan didapatkan dari hasil mengingat seperangkat fakta-fakta, namun hasil dari menemukan sendiri. Lihat Trianto, Mendesain Model Pembelajaran Inovatif Progresif (Jakarta: Kencana, 2010), 114. 
nilai-nilai non-ilmiah. Pendekatan non-ilmiah dimaksud adalah pendekatan yang semata-mata berdasarkan intuisi ${ }^{13}$, akal sehat, prasangka, penemuan melalui coba-coba serta asal berpikir kritis.

Proses pendekatan saintifik dipandu dengan kaidah-kaidah pendekatan ilmiah. Proses pendekatan saintifik dirinci pada tabel 1.

Tabel 1.

Rincian Langkah-langkah Pendekatan Saintifik ${ }^{14}$

\begin{tabular}{|l|l|l|}
\hline $\begin{array}{c}\text { Langkah } \\
\text { Pembelajar } \\
\text {-an }\end{array}$ & Kegiatan Pembelajaran & \multicolumn{1}{c|}{$\begin{array}{c}\text { Pengembangan } \\
\text { Kompetensi }\end{array}$} \\
\hline Mengamati & $\begin{array}{l}\text { Membaca, mendengar, } \\
\text { menyimak, melihat (tanpa } \\
\text { atau dengan alat) }\end{array}$ & $\begin{array}{l}\text { Melatih kesungguhan, } \\
\text { ketelitian, mencari informasi }\end{array}$ \\
\hline Menanya & $\begin{array}{l}\text { Mengajukan pertanyaan } \\
\text { tentang informasi yang } \\
\text { tidak dipahami dari apa } \\
\text { yang diamati atau } \\
\text { pertanyaan untuk } \\
\text { mendapatkan informasi } \\
\text { tambahan tentang apa } \\
\text { yang diamati (dimulai dari } \\
\text { pertanyaan faktual sampai } \\
\text { pertanyaan yang bersifat } \\
\text { hipotetik) }\end{array}$ & $\begin{array}{l}\text { Mengembangkan kreativitas, } \\
\text { rasa ingin tahu, kemampuan } \\
\text { merumuskan pertanyaan } \\
\text { untuk membentuk pikiran } \\
\text { kritis yang perlu untuk hidup } \\
\text { cerdas dan belajar sepanjang } \\
\text { hayat }\end{array}$ \\
\hline $\begin{array}{l}\text { Mengumpul- } \\
\text { kan } \\
\text { informasi/ } \\
\text { eksperimen } \\
\text { melakukan eksperimen, } \\
\text { selain bukumber teks, } \\
\text { mengamati objek/ } \\
\text { kejadian/ aktivitas, } \\
\text { wawancara dengan } \\
\text { narasumber }\end{array}$ & $\begin{array}{l}\text { Mengembangkan sikap teliti, } \\
\text { jujur, sopan, menghargai, } \\
\text { pendapat orang lain, } \\
\text { kemampuan berkomunikasi, } \\
\text { menerapkan kemampuan } \\
\text { mengumpulkan informasi } \\
\text { melalui berbagai cara yang } \\
\text { dipelajari, mengembangkan } \\
\text { kebiasaan belajar dan belajar }\end{array}$ \\
\hline
\end{tabular}

13 Berbeda dengan perspektif pakar Pendidikan Islam, al-Syaibany, yang berpendapat bahwa percaya pada intuisi merupakan bagian dari pengetahuan yang menjadi prinsip Pendidikan Islam. Al-Syaibany menyebut intuisi sebagai pengetahuan yang diperoleh melalui ilham, atau melalui kashf dan hal ini maklum diterima karena agama Islam sebagai wahyu dari Allah. Lihat al-Syaibany, Falsafah, 268.

${ }^{14}$ Lampiran IV Peraturan Menteri Pendidikan dan Kebudayaan Republik Indonesia Nomor 81A Tahun 2013 tentang Implementasi Kurikulum, 5-7. 


\begin{tabular}{|c|c|c|}
\hline & & sepanjang hayat \\
\hline $\begin{array}{l}\text { Mengasosias } \\
\text { i-kan/ } \\
\text { mengolah } \\
\text { informasi }\end{array}$ & $\begin{array}{l}\text { Mengolah informasi yang } \\
\text { sudah dikumpulkan baik } \\
\text { terbatas dari hasil kegiatan } \\
\text { mengumpulkan/ } \\
\text { eksperimen maupun hasil } \\
\text { dari kegiatan } \\
\text { mengumpulkan informasi. } \\
\text { Pengolahan informasi yang } \\
\text { dikumpulkan dari yang } \\
\text { bersifat menambah } \\
\text { keluasan dan kedalaman } \\
\text { sampai kepada pengolahan } \\
\text { informasi yang bersifat } \\
\text { mencari solusi dari } \\
\text { berbagai sumber yang } \\
\text { memiliki penadapat yang } \\
\text { berbeda sampai kepada } \\
\text { yang bertentangan. }\end{array}$ & $\begin{array}{l}\text { Mengembangkan sikap jujur, } \\
\text { teliti, disiplin, taat aturan, } \\
\text { kerja keras, kemampuan } \\
\text { menerapkan prosedur dan } \\
\text { kemampuan berpikir induktif } \\
\text { dalam menyimpulkan }\end{array}$ \\
\hline $\begin{array}{l}\text { Mengomuni } \\
\text { kasikan }\end{array}$ & $\begin{array}{l}\text { Menyampaikan hasil } \\
\text { pengamatan, kesimpulan } \\
\text { berdasarkan hasil analisis, } \\
\text { atau media lainnya }\end{array}$ & $\begin{array}{l}\text { Mengembangkan sikap jujur, } \\
\text { teliti, toleransi, kemampuan } \\
\text { berpikir sistematis, } \\
\text { mengungkapkan pendapat } \\
\text { dengan singkat dan jelas, dan } \\
\text { mengembangkan } \\
\text { kemampuan berbahasa yang } \\
\text { baik dan benar. }\end{array}$ \\
\hline
\end{tabular}

\section{Telaah Lima Langkah Pendekatan Saintifik}

Mengamati merupakan kegiatan empiris yang melibatkan peran pancaindra agar pengamat dapat memotret objek benda secara holistik. ${ }^{15}$ Karena objek yang diamati melibatkan peran pancaindra, maka objek tersebut harus berupa objek fisik-materil. Persoalan inilah yang menjadi perdebatan dalam mapel PAI. Pasalnya, objek kajian dalam PAI bukan hanya berupa objek fisik-materil. PAI juga mengkaji objek metafisik ${ }^{16}$ yakni hal-hal yang berkaitan dengan alam gaib, seperti malaikat, jin, dan setan. Lebih dari itu, PAI bahkan mengkaji aspek eskatologis, seperti alam kubur, alam akhirat, surga dan neraka.

15 Baca Lampiran IV Peraturan Menteri Pendidikan dan Kebudayaan Republik Indonesia Nomor 81 A Tahun 2013 tentang Implementasi Kurikulum, 5-7.

${ }^{16}$ Rosidin, Epistemologi Pendidikan Islam (Yogyakarta: Diandra Kreatif, 2013), 29. 
Bidang kajian metafisik-eskatologis tersebut diturunkan menjadi mata pelajaran Aqidah Akhlaq. ${ }^{17}$

Dalam kegiatan mengamati objek yang metafisik-eskatologis tidak diperkenankan mengada-adakan sesuatu yang tidak bisa dijangkau oleh akal dan indra manusia. Maksudnya, perlu disadari bahwa pancaindra yang diberikan oleh Allah kepada manusia memang hanya mampu mengamati objek yang bersifat fisik-materil. Sementara itu, objek pengamatan yang bersifat metafisik-eskatologis hanya diinformasikan oleh Allah melalui kalâm dan utusan-Nya (baca: alQur'ân dan al-Sunnah). Oleh karena itu, objek yang diinformasikan melalui wahyu tersebut harus berangkat dari sikap percaya (iman) terhadap pernyataan-pernyataan dari wahyu tanpa koreksi sama sekali sehingga ia bersifat a priori. ${ }^{18}$ Dengan menyandarkan pada sifat a priori tersebut, intuisi sebagai kerangka berpikir pendekatan saintifik dalam mapel PAI tidak dapat dinafikan. ${ }^{19}$ Akhirnya, langkah mengamati dalam mapel PAI menggunakan paradigma ganda antara metode empirik dan metode intuitif.

Menanya merupakan kegiatan kedua dalam pendekatan saintifik. Langkah ini bertujuan untuk membuka kesempatan secara luas kepada siswa agar bertanya mengenai apa yang sudah dilihat, disimak, dibaca atau dilihat. Menanya merupakan gerbang awal bagi seseorang memasuki dunia skeptis. Artinya, langkah menanya adalah jalan memasuki dunia rasio. Dalam hal ini, guru perlu membimbing siswa agar bisa mengajukan pertanyaan mengenai hasil pengamatan objek yang konkret sampai kepada yang abstrak. Pertanyaan tersebut bisa bersifat faktual sampai kepada pertanyaan yang bersifat hipotetik. ${ }^{20}$

Kegiatan menanya selayaknya memenuhi gradasi bobot pertanyaan. Sasaran gradasi bobot pertanyaan dibagi menjadi dua, yakni pertanyaan pada kognitif rendah yang meliputi pertanyaan tentang pengetahuan menuju pemahaman hingga ke penerapan. Sasaran gradasi yang kedua yakni kognitif yang lebih tinggi meliputi

\footnotetext{
17 Lihat Peraturan Menteri Agama Nomor 2 Tahun 2008 tentang Standar Kompetensi Lulusan dan Standar Isi.

18 Rosidin, Epistemologi, 30.

19 Anugerah ini disebut sebagai hikmah yang mampu mempersepsi realitas yang tak mampu dipersepsi oleh akal maupun pancaindra. Namun hikmah hanya diberikan oleh Allah kepada para hamba-Nya yang dekat dengan-Nya. Rosidin, Epistemologi, 54-57. Bandingkan dengan Nizar, Pengantar, 147.

${ }^{20}$ Lihat Lampiran IV Peruturan Menteri Pendidikan dan Kebudayaan Republik Indonesia Nomor 81 A Tahun 2013 tentang Implementasi Kurikulum, 5-7.
} 
pertanyaan tentang analisis menuju ke sintesis hingga pertanyaan yang bersifat evaluatif. ${ }^{21}$ Agar lebih memberikan gambaran yang jelas, bobot tingkat pertanyaan disajikan dalam tabel 2 .

\section{Bobot Tingkat Pertanyaan pada Siswa ${ }^{22}$}

\begin{tabular}{|c|c|c|}
\hline $\begin{array}{l}\text { Tingkat } \\
\text { Kognitif }\end{array}$ & Subtingkatan & Kata Kunci Pertanyaan \\
\hline \multirow[t]{3}{*}{$\begin{array}{l}\text { Kognitif yang } \\
\text { lebih rendah }\end{array}$} & $\begin{array}{l}\text { Pengetahuan } \\
\text { (knowledge) }\end{array}$ & $\begin{array}{l}\text { 1) Apa... } \\
\text { 2) Siapa... } \\
\text { 3) Kapan... } \\
\text { 4) Di mana... } \\
\text { 5) Sebutkan... } \\
\text { 6) Jodohkan atau pasangkan... } \\
\text { 7) Persamaan kata... } \\
\text { 8) Golongkan... } \\
\text { 9) Berilah nama... } \\
\end{array}$ \\
\hline & $\begin{array}{l}\text { Pemahaman } \\
\text { (comprehension) }\end{array}$ & $\begin{array}{l}\text { 1) Terangkanlah... } \\
\text { 2) Bedakanlah... } \\
\text { 3) Terjemahkanlah... } \\
\text { 4) Simpulkan... } \\
\text { 5) Bandingkan... } \\
\text { 6) Ubahlah... } \\
\text { 7) Berikanlah interpretasi... }\end{array}$ \\
\hline & $\begin{array}{l}\text { Penerapan } \\
\text { (application) }\end{array}$ & $\begin{array}{ll}\text { 1) } & \text { Gunakanlah... } \\
\text { 2) } \text { Tunjukanlah... } \\
\text { 3) Buatlah... } \\
\text { 4) Demonstrasikanlah... } \\
\text { 5) Carilah hubungan... } \\
\text { 6) Tulislah contoh... } \\
\text { 7) Siapkanlah... } \\
\text { 8) Klasifikasikanlah... } \\
\end{array}$ \\
\hline \multirow[t]{2}{*}{$\begin{array}{l}\text { Kognitif yang } \\
\text { lebih tinggi }\end{array}$} & Analisis (analysis) & $\begin{array}{l}\text { 1) Analisislah... } \\
\text { 2) Kemukakanlah bukti-bukti... } \\
\text { 3) Mengapa... } \\
\text { 4) Identifikasikanlah... } \\
\text { 5) Tunjukanlah sebabnya... } \\
\text { 6) Berilah alasan-alasan... }\end{array}$ \\
\hline & Sintesis (synthesis) & $\begin{array}{l}\text { 1) Ramalkanlah... } \\
\text { 2) Bentuk... }\end{array}$ \\
\hline
\end{tabular}

21 Tentang bobot pertanyaan rujuk modul workshop Model Pembelajaran Saintifik Mata Pelajaran Pendidikan Agama Islam, 12.

22 Dalam modul workshop Model Pembelajaran Saintifik Mata Pelajaran Pendidikan Agama Islam, 12. 


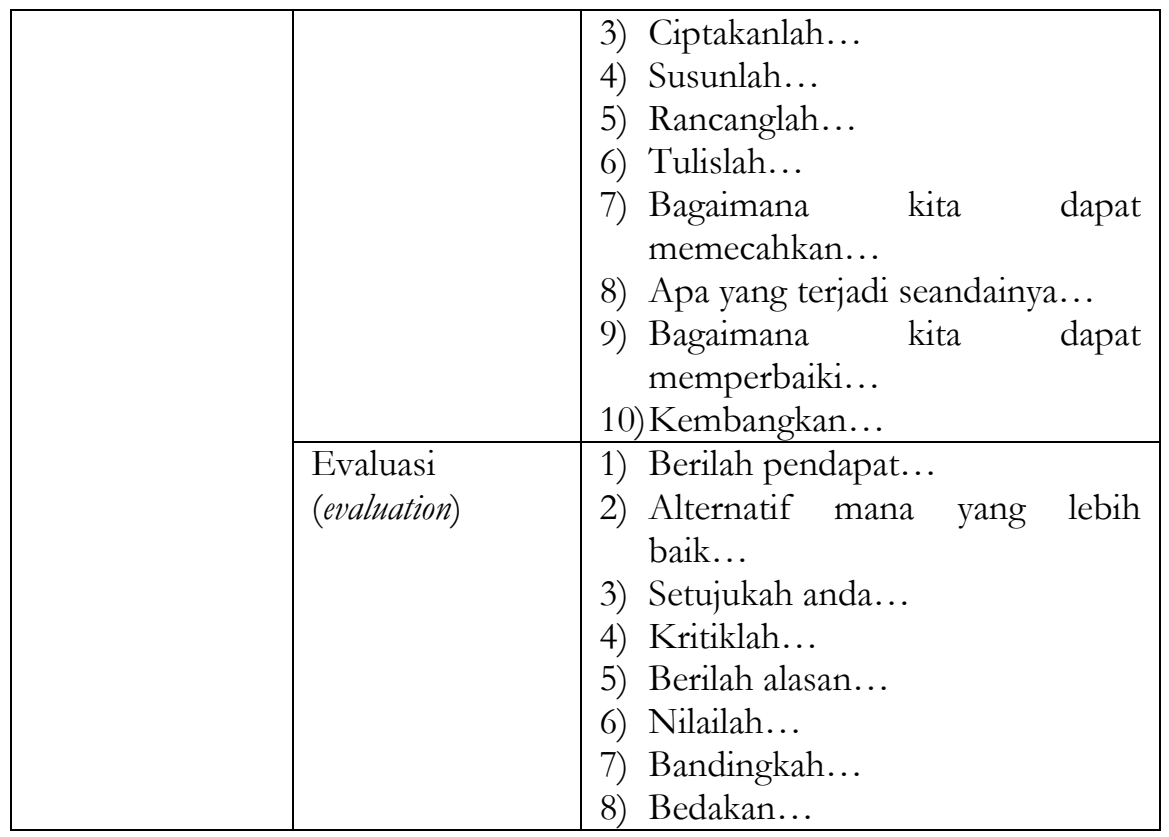

Ahmad Tafsir menyebutkan beberapa dampak positif bila kegiatan bertanya dilakukan dengan maksimal, di antaranya: a) pertanyaan akan menjadi dialog yang berlangsung secara dinamis, karena kedua belah pihak terlibat langsung dalam pembicaraan sehingga dapat mereduksi kebosanan siswa; b) siswa tertarik untuk mengikuti terus pembicaraan karena mereka ingin tahu kesimpulannya; c) pertanyaan yang diiringi dialog akan membangkitkan perasaan dan kesan dalam jiwa yang membantu mengarahkan seseorang menemukan sendiri kesimpulannya; dan d) bila hivwâr dilakukan dengan baik, maka akan menjadi jejak rekam positif terhadap peserta didik. Teladan-teladan yang dicontohkan guru akan mempengaruhi siswa hingga meninggalkan pengaruh berupa pendidikan akhlak. ${ }^{23}$

Langkah ketiga dalam pendekatan saintifik adalah menggali dan mengumpulkan informasi dari berbagai sumber melalui berbagai cara. Agar kegiatan ketiga ini berjalan sukses, siswa dimotivasi untuk membaca buku yang lebih banyak agar memperkaya informasi yang didapat, mempertahankan fenomena atau objek yang lebih teliti, atau bahkan melakukan eksperimen. ${ }^{24}$ Dari kegiatan ini diharapkan siswa

23 Ahmad Tafsir, Ilmu Pendidikan dalam Perspektif Islam (Bandung: Remaja Rosdakarya, 1994), 136.

${ }^{24}$ Lampiran IV Peraturan Menteri Pendidikan dan Kebudayaan Republik Indonesia Nomor 81 A Tahun 2013 tentang Implementasi Kurikulum, 5-7. 
mampu mengumpulkan berbagai informasi agar bisa digunakan untuk langkah selanjutnya yakni asosiasi.

Langkah mengumpulkan informasi senada dengan pendekatan burhânî. Pendekatan burbânî merupakan pendekatan yang menghendaki agar proses pembelajaran didasarkan pada argumentasi yang jelas. Menurut golongan ini pengetahuan dan kebenaran sesuai dengan apa yang ada di dalam dan di luar akal. Teks menjadi alat atau simbol untuk melihat maksud dari makna karena pendekatan ini berangkat dari nalar. ${ }^{25}$

Serangkaian kegiatan mengumpulkan informasi (membaca buku, mengamati objek, aktivitas, wawancara, bahkan eksperimen) merupakan pengayaan dari aktivitas ekplorasi. Menurut Mulkhan, eksplorasi merupakan salah satu metode yang digunakan dalam PAI. ${ }^{26}$ Langkah mengumpulkan informasi ini sangat berguna, karena dapat memberikan injeksi karakter luhur pada siswa berupa sikap teliti, jujur, sopan, dan menghargai pendapat orang lain. ${ }^{27}$ Dengan penanaman karakter luhur tersebut lebih memiliki semangat dalam mengeksplorasi pelajaran dan akan menghidupkan suasana belajar yang ilmiah.

Langkah yang keempat dalam pendekatan saintifik ialah mengasosiasi. Mengasosiasi merupakan serangkaian kegiatan mengumpulkan dan menghubungkan informasi yang telah didapat oleh siswa. Kegiatan ini merupakan proses untuk menemukan keterkaitan satu informasi dengan informasi lainnya. Dalam kegiatan ini, siswa dapat menemukan pola dari keterkaitan informasi dan bahkan dapat mengambil berbagai kesimpulan dari pola yang ditemukan. $^{28}$

Langkah mengasosiasi ini cukup pragmatis karena sangat dipengaruhi langkah-langkah sebelumnya, yakni mengamati, menanya, dan mengumpulkan informasi. Bila langkah sebelumnya dilakukan dengan maksimal, maka pada langkah ini akan timbul sense of inquiry. Hal ini bisa terjadi karena dalam mengasosiasi akan mendorong peserta didik untuk mengonstruk pengetahuan yang didapatkan dari

${ }_{25}$ M. Suyudi, Pendidikan Islam dalam Perspektif al-Qur'ân (Yogyakarta: Mikraj, 2005), 168.

${ }^{26}$ Baca al-Rasyidin dan Syamsul Nizar, Filsafat Pendidikan Islam (Ciputat: Ciputat Press, 2005), 73.

${ }^{27}$ Lampiran IV Peraturan Menteri Pendidikan dan Kebudayaan Republik Indonesia Nomor 81A Tahun 2013 tentang Implementasi Kurikulum, 5-7.

${ }^{28}$ Ibid. 
langkah-langkah sebelumnya. Siswa memecahkan masalah, menemukan sesuatu yang berguna bagi dirinya dan bergelut dengan ide-ide yang mereka temukan. Sehingga pembelajaran menjadi konstruksi bukan menerima pengetahuan.

Adanya komponen konstruksi dalam pembelajaran dapat mendorong pembentukan schemata. Semakin sering konstruksi ini digunakan, schemata siswa lebih berkembang berdasarkan periode kognitif siswa. Aplikasi dalam pembelajaran PAI di kelas bisa berupa praktek mengerjakan materi, menulis gagasan, mendemonstrasikan, menciptakan ide dan lain sebagainya. Bisa jadi konstruk tiap siswa berbeda satu sama lain. Di sinilah tugas guru sebagai fasilitator untuk memberikan bimbingan.

Setelah schemata semakin banyak terbentuk, dalam proses mengasosiasi ini, dengan sendirinya akan timbul sense of inquiry dalam diri siswa. Melalui inquiry inilah pengetahuan perolehan dari siswa didapatkan dari seperangkat fakta-fakta, tetapi hasil dari menemukan sendiri. ${ }^{29}$ Proses inquiry pada siswa meninggalkan rekam jejak memori

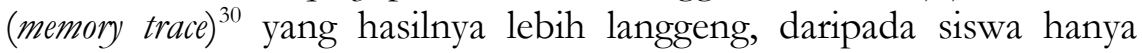
mendengarkan pengetahuan yang bukan berasal dari hasil temuannya sendiri.

Langkah mengasosiasi tergolong metode logik, karena dalam langkah ini siswa benar dilatih mengembangkan potensi pikir sesuai dengan kapasitas yang dimiliki. Hal ini nantinya mendorong tercapainya pengetahuan yang didasarkan pada pengetahuan yang mereka miliki. ${ }^{31}$ Langkah ini bermuara pada pengembangan kemampuan menerapkan prosedur dan kemampuan berpikir induktif dalam menyimpulkan. ${ }^{32}$

Langkah yang terakhir adalah mengomunikasikan. Melalui langkah ini siswa menuliskan atau menceritakan apa yang ditemukan dalam kegiatan mencari informasi, mengasosiasikan dan menemukan pola keterhubungan yang telah dilalui siswa melalui kegiatan tersebut. Hasil

\footnotetext{
${ }^{29}$ Kegiatan inquiry bisa mendorong peserta didik pada proses disequilibrium menuju proses equilibrium. Teori ini merupakan perpaduan antara dua aliran besar dalam kognitif, yakni teori Gestalt dan teori Equilibrium yang diajukan oleh Jean Peaget. Lihat B.R. Hergenhanh dan Matthew H. Olson, An Introduction to Theories of Learning (New Jersey: Prentice-Hall International, Inc., 1997), 284.

${ }^{30}$ Untuk lebih memperdalam trace memory lihat ibid.

${ }^{31}$ Rosidin, Epistemologi, 91.

32 Lihat Lampiran IV Peraturan Menteri Pendidikan dan Kebudayaan Republik Indonesia Nomor 81 A Tahun 2013 tentang Implementasi Kurikulum, 5-7.
} 
yang didapatkan oleh siswa disampaikan di kelas dan dinilai oleh guru sebagai hasil belajar individu atau kelompok. ${ }^{33}$

Serangkaian aktivitas pendekatan saintifik ditutup dengan aktivitas komunikasi. Langkah mengomunikasikan menjadi hal yang penting dalam pendekatan saintifik karena dalam langkah ini sebagai puncak refleksi dan evaluasi siswa dalam serangkaian langkah yang telah dilaluinya. Secara implisit langkah ini mengajarkan siswa beberapa karakter mulia di antaranya adalah kejujuran dalam memperoleh jawaban; apakah jawaban yang mereka peroleh hasil kerja sendiri atau menyontek.

Karakter lain yang diajarkan dalam langkah ini adalah toleransi, karena siswa dianjurkan untuk mempresentasikan hasil yang telah dikerjakan. Merupakan hal yang diketahui bahwa dalam presentasi terdapat banyak perbedaan pendapat. Oleh karena itu, sikap toleransi merupakan pengikat dari pendapat yang berbeda tersebut. Karakter selanjutnya adalah kemampuan berpikir sistematis. Karakter berpikir sistematis ini sangat berguna bagi siswa, karena untuk menyampaikan hasil temuan agar mudah dipahami pendengar, presenter harus memiliki kemampuan berpikir sistematis. Karakter terakhir adalah mengembangkan kemampuan berbahasa yang baik dan benar. ${ }^{34}$ Berbahasa dengan baik dan benar merupakan gejala akhlak karimah yang terefleksi dari lisan. Dengan kata lain, seseorang yang menggunakan lisannya dengan baik, mampu berbicara dengan sopan dan tidak menyinggung perasaan orang lain merupakan aplikasi dari akhlak mulia. Karena yang disebut sebagai seorang Muslim adalah seorang yang mampu menjaga lisan dan tangannya dari menyakiti orang lain.

Dapat disimpulkan bahwa secara garis besar sumber pengetahuan pendekatan saintifik berasal dari empiris-rasio. Mekanisme berpikir yang digunakan adalah analitik-sintetik dengan mempertimbangkan segi aksiologis berupa kegunaan informasi kognitif pada siswa. PAI didasari suatu pemikiran bahwa ilmu adalah milik Allah. Dengan demikian, Allah merupakan Pendidik Yang Pertama dan Utama dan juga Pengajar Pertama. Manusia adalah sebagai siswa. Manusia diberi bekal berupa akal (penalaran) untuk merumuskan teori-teori. Ini merupakan anugerah dari Allah agar akal digunakan untuk melakukan perenungan disertai dengan konfirmasi pengalaman dari panca indra.

\footnotetext{
33 Ibid.,14.

34 Ibid., 5-7.
} 
Pembuktian empiris (panca indra) merupakan kenikmatan agung yang Allah berikan kepada manusia sebagai sarana memperoleh ilmu pengetahuan. Tubuh sebagai tempat bersemayam pancaindra di mana dengannya manusia dapat melihat, meraba, mencium, mendengar dan merasa. Melalui indra, manusia dapat melihat dan mendengar ayatayat yang bertebaran di alam ini baik secara 'aql maupun naql..$^{35}$

Panca indra yang dianugerahkan oleh Allah tidak bisa dipergunakan secara independen, namun ia harus bersinergi dengan akal. Sinergi kedua sarana ini ditegaskan oleh Allah dalam surat alNaḥl [16]: 78:

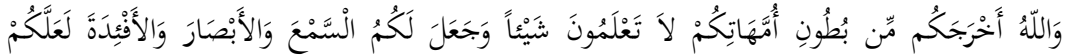
تَشْكُخُونَنَ

"Dan Allah mengeluarkan kamu dari perut ibumu dalam keadaan tidak mengetahui sesuatupun, dan Dia memberi kamu pendengaran, pengelihatan dan hati, agar kamu bersyukur".

Ayat di atas menjelaskan bahwa manusia dilahirkan di dunia tanpa memiliki ilmu sedikitpun. Allah menjadikan akal dan pancaindra manusia sebagai sarana untuk memperoleh pengetahuan. Salah satu contoh kerjasama antara pancaindra dengan akal adalah dengan observasi. Akal digunakan untuk mengetahui dan memahami nilai dan kekuatan hakiki dunia material yang dapat diamati dari pancaindra agar dapat menyibak berbagai rahasia dan keajaiban yang Allah berikan di dunia ini.

Kemudian akal dan panca indra tersebut disinergikan dengan intuisi agar jalan berpikir yang digunakan manusia tidak terlepas dari rel yang diatur oleh Allah. Demikianlah deskripsi alur berpikir yang digunakan oleh saintis Muslim. Dalam al-Qur'ân, Allah mengingatkan bahwa dalam diri manusia terdapat pemberian yang sifatnya samar yang disebut dengan bilkmah. Dalam bahasa sufistik ia disebut alBasîrah al-Mulbimah dan dalam bahasa filsafat disebut dengan intuisi (al-Huds). Hikmah ini mampu mempersepsi realitas yang tak mampu dipersepsi oleh akal maupun pancaindra. Namun bikemah hanya diberikan oleh Allah kepada para hamba-Nya yang dekat dengan-Nya, seperti Q.S. al-Baqarah: [2]: 269:

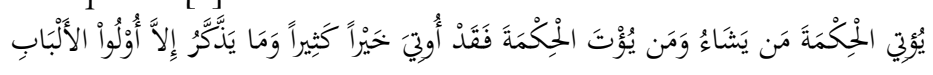

"Allah menganugrahkan al-hikmah (kepahaman yang dalam tentang alQurân dan Sunnah) kepada siapa yang Dia kehendaki. Barangsiapa yang

${ }^{35}$ Rosidin, Epistemologi, 44-46. 
dianugerahi hikmah itu, ia benar-benar telah dianugerahi karunia yang banyak. Hanya orang-orang yang berakallah yang dapat mengambil pelajaran (dari firman Allah)".

Sedangkan dalam Q.S. Luqmân [31]: 12:

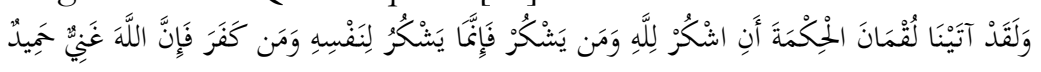

"Sesungguhnya telah Kami berikan hikmah kepada Luqman, yaitu: "Bersyukurlah kepada Allah. Barangsiapa yang bersyukur (kepada Allah), maka sesungguhnya ia bersyukur untuk dirinya sendiri; dan barangsiapa yang tidak bersyukur, maka sesungguhnya Allah Maha Kaya lagi Maha Terpuji".

Dua ayat di atas menjelaskan otoritas Allah dalam memberikan anugerah al-Hikmah itu kepada hamba pilihan-Nya. Sumber pengetahuan intuisi ini berbeda dari sumber pengetahuan yang dihasilkan oleh indra dan akal. Bila sumber yang berasal dari indra dan akal bersifat empiris-rasional, sumber intuisi bersifat metaempirissuprarasional.

Intuisi bisa didapatkan pada orang-orang yang damîr-nya bersih, qalb-nya berkembang, mujâhadah terhadap nafs-nya serius, taqarrub-nya kepada Allah melalui jalur dhikr banyak. Ketika mereka menjalani ini semua secara istiqâmah, maka Allah membukakan ilmu bagi mereka. Mujâhadah semacam ini juga harus ditopang oleh peranan akal dan pancaindra. Hal ini karena pengetahuan intuisi merupakan buah (balasan) dari amal. Demikianlah pendapat al-Kurdî. ${ }^{36}$

Senada dengan pendapat al-Kurdî, Nizar juga menguatkan bahwa intuisi bisa diperoleh dari upaya-upaya keras secara teratur dan dengan ketekunan serta kedisiplinan diri secara mantap dan kuat. Intuisi datang kepada seseorang bila ia siap untuk itu, ketika nalar dan pengalamannya telah terlatih untuk menerima dan menafsirkannya. Tingkatan intuisi yang paling puncak diperoleh para Nabi dan Rasul. Filsuf, mutakallimûn, dan sufi bahkan tidak mampu mencapainya. ${ }^{37}$

Tidak bisa dipungkiri bahwa intuisi dalam PAI sangat diperlukan karena merupakan sumber pengetahuan seperti halnya empiris. Kadir memberikan kesimpulan atas ulasan intuisi dengan mengutip pendapat James, W. T. Stace, dan R.M. Buke bahwa karena keseragaman dan keteraturan pengalaman intuitif, maka sulit untuk dibenarkan bahwa pengalaman itu diperlakukan sebagai halusinasi

\footnotetext{
36 Rosidin, Epistemologi, 54-57.

37 Syamsul Nizar, Pengantar Dasar-dasar Pemikiran Pendidikan Islam (Jakarta: Gaya Media Pratama, 2001), 147.
} 
belaka. Di samping itu jika dapat disetujui pendapat filsuf bahwa pengalaman intuitif benar-benar mempunyai keteraturan dan keseragaman, maka yang demikian sudah cukup untuk dijadikan alasan tentang kebenaran pengalaman itu. Bagi Hairi Yazdi, bilamana masih ada orang yang meragukan pengalaman ini maka ia mempersilakan untuk memasuki lorong pengalaman itu yang sejati, sebagai suatu jalan yang cukup baik untuk kemungkinan menemukan apakah pengalaman itu memang benar-benar asli. Analogi yang dapat ditampilkan dapat diserupakan secara persis dengan sebuah pulau yang belum pernah ditemukan dan hanya dilihat oleh sedikit orang saja; tetapi belum banyak orang lain yang melihatnya, karenanya dianggap sebagai dongeng belaka. Tetapi informasi yang diberikan oleh sedikit orang itu mempunyai keseragaman dan keteraturan. Setiap pengalaman itu sama kuat dan sama baiknya dengan pengalaman lainnya, maka tidak ada alasan untuk menerima satu pengalaman dan menolak yang lainnya. ${ }^{38}$

\section{Dialektika Pendekatan Saintifik dengan PAI}

Pendekatan saintifik menghendaki alur berpikir rasional, kritis dan menitikberatkan kebenaran empiris. Padahal, tidak semua aspek PAI menggunakan alur pikir rasional, kritis, dan hanya mengakui empiris seperti aspek Aqidah. Dalam pendekatan saintifik, metode berpikir intuisi digolongkan bukan merupakan metode berpikir ilmiah karenanya metode semacam itu ditolak. ${ }^{39}$ Sedangkan dalam PAI metode berpikir intuisi justru menjadi prinsip tersendiri untuk memperoleh pengetahuan.

Mereduksi cara berpikir saintifik akan berimplikasi pada metode pengajaran dan proses pembelajaran akan berjalan secara konvensional-tradisional. ${ }^{40}$ Di sisi lain, hanya mengandalkan akal merupakan cerminan egoisme dan arogansi serta menunjukkan betapa sombongnya manusia yang otak dan akalnya merupakan anugerah Tuhan. Akal pada taraf tertentu tidak bisa menembus persoalan yang bersifat transcendent. Dalam hal inilah pendekatan saintifik dan nonsaintifik dalam PAI harus diharmonisir. Pada dasarnya ilmu yang Allah berikan untuk manusia melalui otaknya merupakan bagian ruang

\footnotetext{
38 Abd. Kadir, "Epistemologi Ilmu-ilmu Keislaman dalam Perspektif al-Ghazali", Makalah Tidak diterbitkan, 2014, 21.

39 Lihat Materi Diklat Guru Dalam Rangka implementasi Kurikulum 2013 yang diterbitkan oleh Kementerian Pendidikan dan Kebudayaan, 1-3.

${ }^{40}$ Mujtahid, Reformulasi, 37.
} 
tak terpisahkan dari nilai-nilai ketuhanan. Al-Qur'ân sendiri tidak henti-hentinya menyerukan manusia untuk terus mengkaji, meneliti, menelaah, dan memikirkan segala fenomena yang ada, karena tidak ada sesuatupun di dunia ini yang tercipta dengan sia-sia. ${ }^{41}$ Motivasi yang diberikan tersebut tidak lain agar manusia tahu dan sadar akan potensi akalnya agar menambah keimanan kepada Allah. ${ }^{42}$ Senada dengan pendapat ini, al-Abrosy dalam ulasannya menyebutkan bahwa salah satu tujuan diselenggarakannya PAI adalah untuk menumbuhkan ruh ilmiah (scientific spirit) pada pelajaran dan memuaskan keinginan hati untuk mengetahui (curiousty), sehingga PAI sebetulnya tidak hanya sebatas mengkaji ilmu sebagai studi kajian (yang hanya dikaji tanpa diamalkan). Diharapkan scientific spirit mampu menjadi penggerak dalam rutinitas harian. ${ }^{43}$ Dengan demikian, tidak mungkin pendekatan saintifik dan PAI berpolar dan saling tidak menyapa.

Ketidakpercayaan bahwa terjadi polarisasi alur pikir dalam PAI dikuatkan oleh Ali. Dia berpendapat bahwa PAI mengorientasikan hubungan harmonis antara akal dan wahyu. Dua dimensi tersebut bergerak saling melengkapi satu sama lain. Dalam pandangan PAI, kedudukan akal dan wahyu merupakan saka guru dalam memperoleh ilmu ${ }^{44}$ sehingga jika bisa mengakomodir antara akal dan wahyu akan terwujud peserta didik yang berjiwa tawhîd (berkedalaman spiritual), beramal salîh (berbuat dengan ilmunya), ûlû al-albâb (pemikir, ahli dhikir dan amal salîh), serta berakhlak mulia. ${ }^{45}$

Jika dikaji dalam aspek sejarah, ${ }^{46}$ sebenarnya tidak dijumpai dikotomi ilmu. Abad ke-7 M peradaban Islam menjadi kiblat ilmu pengetahuan dunia. Bahkan ketika Islam menjadi kiblat ilmu pengetahuan, pendidikan Islam yang berkembang adalah pendidikan Islam non-dikotomis yang akhirnya mampu melahirkan banyak intelektual muslim yang memiliki karya sangat besar dan berpengaruh

${ }^{41}$ Baca Q.S Ali 'Imrân [3]: 190-191.

42 Baca Salinan Lampiran Peraturan Menteri Pendidikan dan Kebudayaan Nomor 69 Tahun 2013 tentang Kerangka Dasar dan Struktur Kurikulum Sekolah Menengah Atas/Madrasah Alîyah, 3; dan lihat Salinan Lampiran Peraturan Menteri Pendidikan dan Kebudayaan Nomor 54 Tahun 2013 tentang Standar Kompetensi Lulusan Pendidikan Dasar dan Menengah.

43 Zuhairini, Filsafat Pendidikan Islam (Jakarta: Bumi Aksara, 1995), 165-166.

44 Lihat Muhammad Daut Ali, Pendidikan Agama Islam (Jakarta: Raja Grafindo Persada, 1998), 387.

${ }^{45}$ Lihat Mujtahid, Reformulasi, 35.

${ }^{46}$ Kajian sejarah tentang monokotomi ilmu sudah telah dikaji secara mendalam oleh Baharuddin dkk dalam buku yang berjudul Dikotomi Pendidikan Islam. 
positif terhadap eksistensi kehidupan manusia, seperti Ibnu alHaytham, seorang pelopor di bidang optik; jauh sebelum Roger Bacon, Leonardo da Vinci, Keppler, dan Newton dilahirkan. Dalam bidang astronomi terdapat nama al-Tûusî dari Damaskus yang melakukan penelitian tentang gerakan planet-planet, membuat model planet (planetarium) sebelum Copernicus ada. Al-Fazarî (astronom Islam), Ibn Sînâ (ahli kedokteran sehingga dijuluki doctor of doctors), alBîrunî (filsuf, astronom, ahli geografi, matematika, juga sejarah), Ibn Rushd (filsuf dan faqîh, sehingga dijuluki Averroes) adalah beberapa nama besar lain yang "lahir" dari pendidikan Islam non-dikotomis. ${ }^{47}$ Menurut Barizi stigma ilmu berpolar menjadi dua, yakni ilmu umum dan ilmu agama, bila terus dibiarkan akan menjadi perdebatan yang tidak akan pernah berhenti. Pandangan dikotomis semacam ini mengakibatkan ilmu alam, sosial, humaniora menjadi bagian keilmuan yang tak ada hubungannya dengan ilmu agama. ${ }^{48}$ Akibatnya, menurut Mujtahid, mindset ini sulit disatukan sehingga metodologi berpikir saintifik dalam memperoleh ilmu ditolak oleh kalangan kolot. ${ }^{49}$

Kekeliruan menempatkan alur pikir mengakibatkan pembelajaran PAI menjadi kolot dan tidak menerima cara berpikir kritis seperti yang digunakan oleh saintis. Untuk meluruskan mindset ini ilmu agama (Islam) menjadi pondasi dan penguat untuk menyanggah ilmu umum yang bermacam-macam cabangnya. Dengan demikian, orang yang berprofesi sebagai guru, pedagang, politikus, dokter, pengacara, dan lainnya memiliki nilai etis religius yang kuat karena mereka memiliki ilmu agama sebagai modal dasar.

Dampaknya, jika ilmu umum berjalan sendiri, maka terkesan ia bebas nilai sehingga profesi itu menjadi bebas dan tidak terikat dengan nilai-nilai ilâhîyah dan insânîyah serta norma-norma ajaran Islam yang dilandaskan pada al-Qur'ân dan Hadîth. Integrasi ilmu semacam ini perlu dikonsep secara matang. ${ }^{50}$ Rasulullah bersabda bahwa setiap Muslim, baik lelaki maupun perempuan, diwajibkan menuntut ilmu. Ini tidak berarti bahwa ilmu agama wajib dipelajari sementara ilmu umum tidak wajib atau orang yang menuntut ilmu agama akan

\footnotetext{
${ }^{47}$ Baharuddin, dkk., Dikotomi Pendidikan Islam (Bandung: Remaja Rosdakarya, 2011), $\mathrm{x}$.

48 Ahmad Barizi, Pendidikan Integratif Akar Tradisi dan Integrasi Keilmuan Pendidikan Agama Islam (Malang: UIN Press, 2011), 20-25.

${ }^{49}$ Mujtahid, Reformulasi Pendidikan Islam (Malang: UIN Maliki Press, 2011), 32-35.

${ }^{50}$ Ibid., 32-35.
} 
ditinggikan derajatnya oleh Allah sementara ilmuwan non-agama tidak. $^{51}$

Ayat-ayat dalam al-Qur'ân di bawah ini akan membuktikan bahwa alur pikir ilmiah dan agama terintegrasi. Ayat-ayat di bawah mengintruksikan manusia untuk selalu berpikir secara ilmiah tentang ciptaan Allah yang meliput segala apa yang ada di langit maupun di bumi. Hal ini seperti yang terdapat dalam surat Ali 'Imrân [3]: 189190:

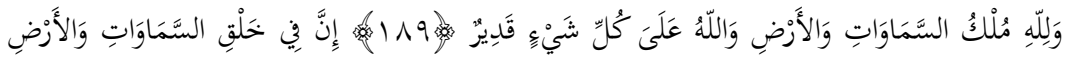

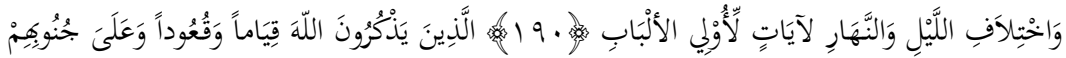

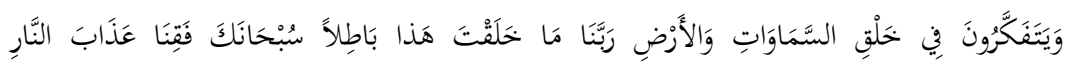

$$
\begin{aligned}
& \text { 1919 }
\end{aligned}
$$

"Kepunyaan Allah-lah kerajaan langit dan bumi, dan Allah Maha Kuasa atas segala sesuatu. Sesungguhnya dalam penciptaan langit dan bumi, dan silih bergantinya malam dan siang terdapat tanda-tanda bagi orang-orang yang berakal. (yaitu) orang-orang yang mengingat Allah sambil berdiri atau duduk atau dalam keadaan berbaring dan mereka memikirkan tentang penciptaan langit dan bumi (seraya berkata): "Ya Tuhan kami, tiadalah Engkau menciptakan ini dengan sia-sia. Maha Suci Engkau, maka peliharalah kami dari siksa neraka".

Selanjutnya, dalam Q.S. al-Naḥl: [16]: 114 dijelaskan sebagai berikut:

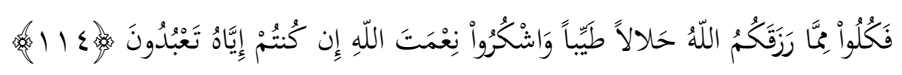

"Maka makanlah yang halal lagi baik dari rejeki yang telah diberikan Allah kepadamu; dan syukurilah nikmat Allah jika kamu hanya kepadaNya saja menyembah".

Ayat-ayat di atas mengintruksikan kaum beriman untuk bertafak.kûr terhadap ciptaan Allah (Q.S. Ali 'Imrân [3]: 189-190) dan ber-tashakkk̂ur (Q.S. al-Nahl: [16]: 114). Perintah memikirkan segala ciptaan Allah di langit dan di bumi melalui hukum-Nya di dalam alQur'ân mengandung pengertian bahwa sains merupakan jalan untuk mendekati kebenaran Tuhan. Hal ini karena kata fakkara sering diterjemahkan dengan to reflect (merefleksi). Dalam bahasa Indonesia kata ini mengandung makna merenung. Perenungan harus diimbangi dengan zikir, karena ketika pikir tidak bisa bicara akan kebenaran maka panggilan iman (zikir) akan memberikan justifikasi ke arah

51 Lihat Jasa Ungguh Muliawan, Pendidikan Islam Integratif (Yogyakarta: Pustaka Pelajar, 2005), vii. 
kebenaran sesungguhnya. Sedangkan tashakkêr berarti memanfaatkan nikmat dan karunia Allah dengan akal modern sehingga kenikmatan itu bertambah kebaikannya atau mengandung berkah. Dalam istilah modern, bersyukur berarti memanfaatkan segenap kemampuan teknologi secara maksimal dan positif untuk mengharmonikan kedua

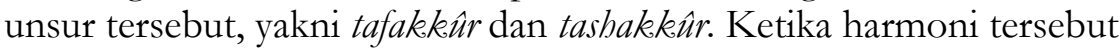
terwujud maka akan melahirkan apa yang disebut dengan ûlû al-albâb (orang-orang yang berakal). ${ }^{52}$

Mencermati uraian di atas, sebenarnya pendekatan saintifik dan PAI memiliki integrasi. Hanya saja, PAI lebih memiliki paradigma ganda yakni rasional dan supra-rasional, karena intuisi menjadi alur pikir yang tidak bisa dinafikan terutama aspek Aqidah. ${ }^{53}$ Ilmu yang diberikan Allah untuk manusia melalui akalnya merupakan bagian yang tidak terpisahkan dari nilai-nilai ketuhanan, karena sumber ilmu yang hakiki adalah Allah. Karena itulah al-Qur'ân selalu menyerukan manusia untuk terus mengkaji, meneliti, menelaah, memikirkan serta menelaah segala fenomena yang ada, karena tidak ada sesuatupun di dunia ini yang tercipta dengan sia-sia. ${ }^{54}$

\section{Menepis Pandangan Dikotomi}

Dalam PAI, wahyu dan akal merupakan dua sarana untuk memperoleh kebenaran. Wahyu merupakan sumber utama dalam ajaran Islam. Oleh karena itu, ia harus ditempatkan sebagai sumber utama dalam setiap proses dan usaha berpikir. 'Abd al-Fattâh Jalâl menegaskan bahwa al-Qur'ân dan Hadîth (al-Sunnah) sepatutnya dijadikan sumber asasi ilmu kependidikan. Al-Nadwî mempertegas bahwa pendidikan dan pengajaran umat Islam harus bersumberkan kepada 'aqîdah islamîyah. Sekiranya pendidikan Islam tidak didasarkan kepada aqidah yang bersumberkan kepada al-Qur'ân dan Hadîth, maka pendidikan yang dilaksanakan bukanlah pendidikan Islam, melainkan pendidikan asing. ${ }^{55}$ Oleh karena itu, al-Shaybanî juga menegaskan bahwa metode dalam pendidikan Islam harus memiliki asas agama, yakni prinsip-prinsip, asas-asas, dan fakta-fakta umum yang diambil dari sumber asasi ajaran Islam, yakni al-Qur'ân dan Sunnah Rasul..$^{56}$

\footnotetext{
52 Barizi, Pendidikan Integratif, 23.

53 Pendapat ini diperkuat oleh Mujtahid. Mujtahid, Reformulasi, 32-35.

${ }^{54}$ Baca Q.S. Ali 'Imrân [3]: 190-191.

${ }^{55}$ Rosidin, Epistemologi, 41.

${ }^{56}$ Al-Rasyidin dan Nizar, Filsafat, 68.
} 
Di sisi lain, akal bagi manusia memiliki peran penting. Akal memiliki keahlian dalam mengamati dunia dan menafsirkan kejadiankejadian di dalamnya. Akal juga memiliki kemampuan menghubungkan tanda-tanda dan simbol-simbol yang diraih lewat indra untuk kemudian menafsirkannya. Oleh karena itu, melalui akal manusia dapat memperoleh pengetahuan rasional-empiris, yakni pengetahuan yang diperoleh melalui pemikiran akal dan hasilnya dapat diverifikasi secara indrawi sebab perolehannya melalui bantuan indra. Peran penting akal yang lain adalah kemampuannya menalar pengetahuan rasional-idealis, yaitu pengetahuan yang diperoleh melalui pemikiran akal namun hasilnya tidak dapat diverifikasi dengan indra akan tetapi ia dapat dibuktikan dengan argumentasi logis. ${ }^{57}$

Keduanya (wahyu dan akal) tidak boleh dikesampingkan. Keduanya harus berjalan beriringan dan berhubungan dengan harmonis. Nizar menegaskan bahwa di antara dua sarana tersebut harus teringerasi, meskipun memiliki karakteristik yang berbeda. ${ }^{58}$ Akal berusaha bekerja maksimal untuk menemukan dan mengembangkan ilmu dengan pengamatan secara empiris. Sedangkan wahyu digunakan sebagai pembimbing dan petunjuk yang harus dilalui oleh akal. ${ }^{59}$

Mengenyampingkan salah satu dari dua sarana tersebut untuk memperoleh kebenaran hanya akan mengakibatkan problem dikotomi ilmu pengetahuan. Ironisnya, problem dikotomi tersebut ditudingkan kepada pendidikan Islam. Pelaku utama dalam hal ini adalah alGhazâlî. Persepsi polarisasi keilmuan tersebut berangkat dari paradigma yang salah. Kadir menjelaskan bahwa secara epistemologis al-Ghazâlî memberikan testimoni terhadap semua pengetahuan yang pernah dipelajarinya dari berbagai disiplin ilmu, dan tidak melupakan memberikan judgment terhadap validitasnya. Elaborasinya memberikan kesan kedalaman dan penguasaan terhadap berbagai ilmu sehingga judgment-nya terhadap berbagai ilmu yang empirik, rasional, maupun spiritual memenuhi standar ilmiah yang diperlukan. Pada dasarnya dia mengakui validitas berbagai macam ilmu pada levelnya masingmasing; namun bilamana harus dibandingkan masing-masing kedudukannya, maka dia lebih mengedepankan validitas pengalaman spiritual. Pengalaman semacam itu, dalam perspektif sains modern,

\footnotetext{
${ }^{57}$ Rosidin, Epistemologi, 51-53.

${ }^{58}$ Nizar, Dasar-dasar, 146.

${ }^{59}$ Qomar, Epistemologi, 143.
} 
sangat jelas dan begitu kuat ditolak karena dianggap hanya sebagai ilusi. Oleh karena itu, al-Ghazâlî membangun argumen yang sangat logis akan kebenaran pengalaman yang bersifat langsung dan secara performatif tanpa perantara representasi mental atau simbolisme kebahasaan apapun. ${ }^{60}$

Qomar memberikan penjelasan yang menarik mengenai problem dikotomi. Sebenarnya, dikotomi merupakan persepsi ilmuwan Barat yang tidak menerima wahyu sebagai sarana memperoleh kebenaran (baca: pengetahuan). Implikasinya, terjadi pemisahan antara wahyu dan akal. Mereka dapat menerima, bahkan menerapkan, bahwa akal sebagai alat untuk mendapatkan kebenaran pengetahuan. Namun mereka menolak wahyu sebagai alat yang dipakai untuk mendapatkan pengetahuan ilmiah. Di kalangan mereka terjadi dikotomi secara tajam antara wahyu dan akal. Bagi mereka wahyu terlepas dari akal, sedangkan akal sendiri mereka yakini tidak memiliki hubungan sama sekali dengan wahyu. Keduanya bergerak dalam wilayah yang berbeda.

Di samping cara pandang yang tidak mau menerima kebenaran wahyu, mereka juga mendapat pengalaman pahit, sehingga pandangan ilmuwan Barat semacam ini dapat dimaklumi. Secara historis, sebelum masa renaissance, telah terjadi pertentangan yang hebat antara doktrin agama dengan temuan ilmu pengetahuan yang menyebabkan banyak terjadi korban di kalangan ilmuwan. Di antara korban tersebut adalah Giordano Bruno dan Galileo Galilei. Keduanya menjadi korban dikotomi keilmuan karena menemukan fakta yang berlawanan dengan otoritas penguasa agama. Akibatnya, mereka mendapatkan ganjaran atas temuan mereka, yaitu dibakar hidup-hidup. ${ }^{61}$ Untung kasus tersebut tidak pernah terjadi dalam dunia Islam. Secara historis maupun substansial, Islam tidak bertentangan dengan ilmu pengetahuan beserta metode yang digunakan oleh saintis dalam memperoleh kebenaran. Dalam sejarahnya, Islam dapat mencapai kejayaan (terutama pada masa dinasti 'Abbâsîyah) justru karena semangat mengembangkan ilmu pengetahuan. ${ }^{62}$

${ }^{60}$ Abd. Kadir, "Epistemologi Ilmu-ilmu Keislaman dalam Perspektif al-Ghazali", Makalah Tidak diterbitkan, 2014, 1.

${ }^{61}$ Baharuddin, dkk., Dikotomi, 19.

${ }^{62}$ Qomar, Epistemologi, 147. Nupiah menjelaskan bahwa masa dinasti Abbashîyah ilmu pengetahuan dipandang sebagai sesuatu yang sangat penting dan mulia. Para khalifah dan pembesar membuka kemungkinan seluas-luasnya untuk kemajuan dan perkembangan ilmu pengetahuan. Syamsul Nizar (ed.), Sejarah Pendidikan Islam (Jakarta: Kencana, 2007), 68. 
Ilmu tanpa didampingi agama akan menyimpang dari akidah yang benar dan cenderung mendewakan akal. Di sisi lain, agama tanpa didampingi ilmu akan dirasakan hanya sebagai doktrin-doktrin kering yang membelenggu penalaran dan pemikiran seseorang, karena tidak ada penjelasan-penjelasan yang memadai dari agama. Sebaliknya, yang ada hanya ketentuan-ketentuan normatif saja. ${ }^{63}$ Demikianlah sikap Islam terhadap ilmu pengetahuan yang sejak dahulu tidak mengenal adanya dikotomi. Islam memiliki sikap yang jelas, yaitu menyerap dan memilah-milah dengan aksioma yang selalu sama tidak pernah berubah, yakni mengambil yang terbaik dan menolak yang buruk. ${ }^{64}$

Ismâî̀l Râjî al-Fârûqî menegaskan bahwa pemisahan wahyu dan akal sama sekali tidak dapat diterima, sebab hal ini bertentangan dengan keseluruhan spirit Islam. Kondisi ini melawan inti seruan alQur'ân untuk mempertimbangkan sesuatu secara rasional dan berusaha merasionalisir makna yang di atas jangkauan akal. ${ }^{65}$

Akal hanya dapat menalar dan mengobservasi benda-benda yang bersifat indrawi (observable fact). Selain itu semua sudah tidak dapat dijangkau oleh akal. Sedangkan wahyu mencakup pemberitaan yang tidak terjangkau oleh indra dan akal. Padahal masih banyak kebenaran yang terdapat pada sesuatu yang berada di luar jangkauan indra maupun akal. ${ }^{66}$

Akal dan wahyu harus saling menunjang. Ketika menjelaskan fakta, kemampuan rasional menjadi dominan. Sebaliknya, ketika berhubungan dengan transendensi, maka intuisi cenderung dominan. Keduanya memiliki wilayah pusat perhatian yang sama-sama efektif dalam memahami kebenaran pada wilayahnya masing-masing. Dengan menggunakan kedua sarana ini, yakni akal dan intuisi, corak pemahaman kebenaran yang diperoleh seseorang bisa bersifat ganda. Pemahaman pertama adalah pemahaman terhadap yang empiris berikut ciri-cirinya. Pemahaman kedua adalah metaempiris, bahkan transendetal disertai karakternya. Jadi, kerjasama keduanya mampu memberikan pemahaman atau pengetahuan bukan hanya berdimensi tunggal, melainkan berdimensi ganda, yakni faktual dan spiritual,

\footnotetext{
${ }^{63}$ Qomar, Epistemologi, 145.

${ }^{64}$ Syamsul Ma'arif, Revitalisasi Pendidikan Islam (Yogyakarta: Graha Ilmu, 2007), 33.

${ }^{65}$ Qomar, Epistemologi, 149.

${ }^{66}$ Ibid., 131. Berkaitan dengan kebenaran wahyu, Langgulung menegaskan bahwa wahyu sebagai sumber (kebenaran) tertinggi dalam pendidikan Islam. Lihat Langgulung, Asas-asas, 349.
} 
lahiriah dan ruhaniah, empiris dan metaempiris (fisik dan metafisik), keduniaan dan keakhiratan (eskatologis). ${ }^{67}$

Bertolak dari pandangan bahwa ilmu berasal dari Allah, maka saintis harus memiliki kepedulian yang besar terhadap agama (Islam) atau memiliki kerangka berpikir theocentric oriented. Artinya, saintis harus menyertakan nilai-nilai ketuhanan sebagai pedoman agar "ijtihad" yang dia lakukan membawa kesejahteraan dan kedamaian bagi semua makhluk. Karena itulah Muhammad Imarah menyatakan bahwa ilmu dalam Islam menjadi media menumbuhkan ketakwaan kepada Allah. ${ }^{68}$

Kerangka berpikir theocentric oriented mengandung arti adanya keinginan "menyucikan" gaya berpikir yang digunakan oleh atheis yang justru semakin menjauhkan dirinya dari fitrah ke-Tuhan-an dan di sisi lain juga ingin mendekonstruksi ilmuwan yang dengan lantang meneriakkan jargon "Tuhan telah mati!" Theosentris oriented dapat membentuk saintis yang beriman yang memandang fakta empirik sebagai sesuatu yang tidak terlepas dari fakta metafisik. ${ }^{69}$

Analisis kerangka berpikir yang terakhir adalah bahwa pendekatan sains harus terikat dengan nilai. Kerangka berpikir dalam pendidikan Islam tidak boleh lepas dari nilai, karena dalam Islam ilmu harus didasarkan nilai serta harus memiliki fungsi dan tujuan. Dengan kata lain, pengetahuan dipergunakan bukan untuk kepentingan manusia sendiri, melainkan pengetahuan harus bisa menyajikan jalan keselamatan. ${ }^{70}$ Aspek inilah yang membedakannya dengan metode pendekatan sains di Barat yang berusaha membebaskan ilmu dari nilai $^{71}$ (tidak boleh terikat nilai tertentu). Bahkan, menurut pandangan Barat, salah satu syarat keilmiahan ialah bersifat objektif. Sifat objektif ini berarti menyatakan fakta apa adanya dan tidak boleh dipengaruhi oleh fakta apa pun. ${ }^{72}$

Alur berpikir seperti di atas berimplikasi kepada terciptanya ilmu pengetahuan yang berwatak "bengis" yang menyebabkan manusia modern melihat manusia dan lingkungan hanya sebagai objek di mana tidak ada tanggungjawab moral dan etik terhadap objek tersebut. Bila perspektif ini terus berlanjut dan lepas kontrol, maka tidak mengherankan jika sains dan teknologi terus melaju sedangkan akhlak

${ }^{67}$ Qomar, Epistemologi, 153.

${ }^{68}$ Ibid., 155.

${ }^{69}$ Ibid., 156.

70 Ibid., 162.

${ }^{71}$ Bandingkan dengan Ma'arif, Revitalisasi, 63.

72 Qomar, Epistemologi, 159. 
dan moral manusia terus mengalami degradasi. Kondisi semacam ini terkonstruk akibat sains yang dibangun tidak berlandaskan nilai.

Menurut Arifin, manusia pada zaman modern ini banyak menghadapi tantangan dan ancaman demoralisasi yang menimbulkan keresahan dan derita hidup. Dia menggambarkan bahwa saat ini kita berada di tengah-tengah bangsa yang menjadikan keterampilan (keahlian) manusia sebagai alat dan kebodohan manusia sebagai tujuan. Setiap bertambah keahlian yang dibutuhkan untuk mencapai tujuan itu maka keahlian tersebut digunakan untuk mencapai kejelekan. Dari sini manusia hidup berkat kebodohan dan ketiadaan keahlian. Tetapi, pengetahuan dan kompetensi yang diperoleh dikombinasikan dengan ketololannya itu justru tidak memberikan arah tertentu dari hidupnya. Dengan kata lain, jika manusia tidak bertambah kebijakan dan kebajikannya sama besarnya dengan pengetahuannya maka pertambahan pengetahuannya hanya akan menambah kesengsaraan.

Oleh karena itu, pendidikan Islam harus mampu menciptakan manusia muslim yang berilmu tinggi di mana keimanan dan ketakwaannya menjadi pengendali dalam penerapan atau pengamalannya dalam masyarakat manusia. ${ }^{73}$

Memahami implikasi yang begitu mengkhawatirkan, tidak mengherankan jika tradisi keilmuan Islam memiliki perhatian yang besar terhadap nilai sejak dini. Dalam perspektif pendidikan Islam, nilai diyakini memiliki peran yang besar untuk menuntun perkembangan pengetahuan, sehingga pertimbangan aksiologis selalu ditempatkan menyertai pertimbangan epistemologis. Hal ini dilakukan agar di samping mampu mencapai kemajuan, sains juga mampu mempertahankan keutuhan moralitas yang positif. $^{74}$

\section{Kontekstualisasi Pendekatan Saintifik-PAI}

Mekanisme berpikir pendekatan saintifik kurikulum 2013 memiliki sinergi dengan mekanisme berpikir yang digunakan dalam PAI, meskipun ada aspek yang tidak sejalan, seperti intuisi. Kesinergian kedua mekanisme tersebut adalah karena PAI tidak memiliki pandangan polarisasi keilmuan (dikotomi keilmuan). PAI memiliki pandangan integratif antara ilmu umum (science) dan ilmu agama. ${ }^{75}$

\footnotetext{
${ }^{73}$ Arifin, Filsafat, 112.

${ }^{74}$ Qomar, Epistemologi, 161-162.

${ }^{75}$ Mujtahid, Reformulasi, 32-35.
} 
Beberapa bukti bahwa pendekatan saintifik bersinergi dengan mekanisme berpikir dalam PAI adalah bahwa pendekatan saintifik bercirikan penonjolan pada dimensi pengamatan, penalaran, penemuan, pengabsahan, dan penjelasan tentang suatu kebenaran. ${ }^{76}$ Dalam PAI mekanisme berpikir semacam ini merupakan optimalisasi empat sumber pengetahuan, yakni wahyu, pancaindra, akal, dan intuisi. ${ }^{77}$

Dimensi pengamatan dalam pendekatan saintifik mengharuskan observer (orang yang melakukan pengamatan) memberdayakan pancaindranya untuk menyelidiki fakta dan fenomena yang tersebar di jagad raya untuk dikumpulkan dan diformulasikan untuk selanjutnya menjadi hipotesis (pada proses selanjutnya yakni penalaran). Dimensi pengamatan melibatkan dua sumber pengatahuan yakni sumber wahyu dan sumber pancaindra. Kedua sumber pengetahuan tersebut merupakan karunia agung yang diberikan Allah kepada manusia agar mengobservasi ayat-ayat Allah yang tersurat (dalam wahyu) maupun yang tersirat (secara kawniyah). Penyelidikan pada ayat-ayat Allah yang berbasis fakta dalam esensi pendekatan ilmiah disebut sebagai inductive reasoning (penalaran induktif).

Namun tidak semua fakta bisa diempiriskan melalui panca indra. Hal ini menjadi maklum, karena fasilitas yang diberikan Allah berupa panca indra memiliki keterbatasan. Panca indra tidak akan mampu menyelidiki fakta-fakta yang ghayb. Pendekatan yang digunakan untuk dimensi pengamatan adalah memposisikan iman di atas pengamatan. Apabila indra tidak bisa mengempiriskan fakta-fakta yang ghayb, maka Allah yang lebih Mengetahui perkara-perkara tersebut.

Dimensi penalaran dalam pendekatan saintifik yakni aktivitas menerjemahkan fakta-fakta yang telah diperoleh panca indra menjadi partikel-partikel agar bisa diterima oleh akal dan bisa dipahami oleh orang lain. Dalam pandangan PAI, menalar merupakan pengoordinasian antara panca indra dengan dengan akal untuk menafsirkan kejadian-kejadian atau fakta-fakta. Melalui indra manusia memperoleh pengetahuan empiris, sedangkan melalui akal manusia memperoleh pengetahuan yang rasional. ${ }^{78}$ Salah satu langkah untuk mengoptimalisir dimensi menalar adalah mengasosiasi. Mengasosiasi merupakan

\footnotetext{
${ }^{76}$ Dalam Materi Diklat Guru Dalam Rangka implementasi Kurikulum 2013 yang diterbitkan oleh Kementerian Pendidikan dan Kebudayaan, 1-3.

${ }_{77}$ Rosidin, Epistemologi, 41

${ }^{78}$ Ibid., 51-53.
} 
serangkaian kegiatan mengumpulkan dan menghubungkan informasi. Kegiatan ini merupakan proses untuk menemukan keterkaitan satu informasi dengan informasi lainnya. Hasil dari aktivitas ini adalah temuan pola dari keterkaitan informasi dan bahkan mengambil berbagai kesimpulan dari pola yang ditemukan. ${ }^{79}$ Mengasosiasi tergolong dalam metode logik, karena dalam langkah ini peserta didik benar-benar dilatih mengembangkan potensi pikir sesuai dengan kapasitas dan potensinya. Hal ini nantinya mendorong tercapainya pengetahuan yang didasarkan pada pengetahuan yang mereka miliki. ${ }^{80}$ Akhirnya, langkah ini bermuara pada pengembangan kemampuan menerapkan prosedur dan kemampuan berpikir induktif dalam menyimpulkan. ${ }^{81}$

Dimensi yang terakhir adalah pengabsahan atau penjelasan tentang kebenaran. Dalam pendekatan saintifik, dimensi ini merupakan hasil akhir dari serangkaian proses penyelidikan dan penalaran. Saintis Barat menganggap bahwa proses penyelidikan, penalaran dan pengabsahan kebenaran merupakan serangkaian kegiatan memperoleh ilmu pengetahuan yang objektif dan netral. ${ }^{82}$ Qomar menolak pandangan yang demikian, karena sikap semacam ini menyebabkan manusia modern melihat manusia dan lingkungan sebagai objek semata, tidak ada tanggungjawab moral dan etik terhadap objek tersebut. Di sinilah peran PAI untuk mengontrol laju pendekatan saintifik yang objektif tersebut menjadi berbasis nilai. Mengetahui dampak yang demikian, pengabsahan tentang kebenaran yang objektif dalam pendekatan saintifik lebih elok dimodifikasi menjadi pengabsahan tentang kebenaran berbasis nilai.

Harapannya, pendekatan saintifik dapat menciptakan saintis yang beriman dan memandang fakta empiris sebagai sesuatu yang tidak terlepas dari fakta metafisik. Dengan demikian, metode berpikir dalam PAI diorientasikan pada hubungan yang harmonis antara akal dan wahyu. Artinya, orientasi PAI ditekankan pada integrasi antara iman, ilmu, amal, dan akhlak. Semua dimensi ini bergerak saling melengkapi

\footnotetext{
${ }^{79}$ Lampiran IV Peraturan Menteri Pendidikan dan Kebudayaan Republik Indonesia Nomor 81A Tahun 2013 tentang Implementasi Kurikulum, 5-7.

${ }^{80}$ Rosidin, Epistemologi, 91.

81 Lihat Lampiran IV Peraturan Menteri Pendidikan dan Kebudayaan Republik Indonesia Nomor 81 A Tahun 2013 tentang Implementasi Kurikulum, 5-7.

${ }^{82}$ Qomar, Epistemologi, 159.
} 
satu sama lainnya. Kedudukan akal dan wahyu dalam pandangan PAI merupakan saka guru dalam memperoleh ilmu pengetahuan. ${ }^{83}$

\section{Penutup}

Pendekatan saintifik merupakan serangkaian mekanisme berpikir yang tidak terpisahkan dalam PAI. Hal ini dibuktikan dengan corak kedua mekanisme berpikir tersebut yang saling terintegrasi. Selain itu, PAI tidak mengenal polarisasi keilmuan. Sebaliknya, PAI memiliki pandangan yang integratif antara ilmu umum dan ilmu agama. Meskipun demikian, keduanya memiliki karakteristik tersendiri. Pendekatan saintifik bercirikan penonjolan dimensi pada pengamatan, penalaran, penemuan, dan pengabsahan. Dimensi ini bersifat empiris, rasional, logis dan objektif. Sementara itu, PAI bercirikan penonjolan pada dimensi wahyu, panca indra, akal, dan intuisi. Dimensi ini bersifat suprarasional, empiris, rasional, logis, metaempiris dan terikat nilai. Dengan karakteristik yang demikian, keduanya tidak bisa berdiri sendiri-sendiri melainkan terdapat interdependensi antara satu dengan lainnya.

\section{Daftar Rujukan}

Ali, Muhammad Daut. Pendidikan Agama Islam. Jakarta: Raja Grafindo Persada, 1998.

al-Rasyidin dan Syamsul Nizar, Filsafat Pendidikan Islam. Ciputat: Ciputat Press, 2005.

al-Syaibany, Omar Mohammad al-Toumy. Falsafah Pendidikan Islam, terj. Hasan Langgulung. Jakarta: Bulan Bintang, 1975.

Baharuddin, dkk. Dikotomi Pendidikan Islam. Bandung: Remaja Rosdakarya, 2011.

Barizi, Ahmad. Pendidikan Integratif Akar Tradisi dan Integrasi Keilmuan Pendidikan Agama Islam. Malang: UIN Press, 2011.

Hergenhanh, B.R., dan Olson, Matthew H. An Introduction to Theories of Learning. New Jersey: Prentice-Hall International, Inc., 1997.

Kadir, Abd. "Epistemologi Ilmu-ilmu Keislaman dalam Perspektif alGhazali", Makalah Tidak diterbitkan. 2014.

Kusaeri. "Evaluasi Penerapan Kebijakan Pendekatan Saintifik pada Kurikulum 2013 dari Perspektif Pendidikan Islam”. Surabaya: Lembaga Penelitian Universitas Islam Negeri Sunan Ampel, 2014.

${ }^{83}$ Ali, Pendidikan, 387. 
Ma'arif, Syamsul. Revitalisasi Pendidikan Islam. Yogyakarta: Graha Ilmu, 2007.

Mujtahid. Reformulasi Pendidikan Islam. Malang: UIN Maliki Press, 2011.

Muliawan, Jasa Ungguh. Pendidikan Islam Integratif. Yogyakarta: Pustaka Pelajar, 2005.

Nizar, Syamsul (ed.). Sejarah Pendidikan Islam. Jakarta: Kencana, 2007.

-----. Pengantar Dasar-dasar Pemikiran Pendidikan Islam. Jakarta: Gaya Media Pratama, 2001.

Rosidin. Epistemologi Pendidikan Islam. Yogyakarta: Diandra Kreatif, 2013.

Rusman. Model-model Pembelajaran Mengembangkan Profesionalisme Guru. Jakarta: PT RajaGrafindo Persada, 2012.

Suyudi, M. Pendidikan Islam dalam Perspektif al-Qur'ân. Yogyakarta: Mikraj, 2005.

Tafsir, Ahmad Ilmu Pendidikan dalam Perspektif Islam. Bandung: Remaja Rosdakarya, 1994.

Trianto, Mendesain Model Pembelajaran Inovatif Progresif. Jakarta: Kencana, 2010.

Zuhairini. Filsafat Pendidikan Islam. Jakarta: Bumi Aksara, 1995. 